\title{
Teaching Black History After Obama
}

\author{
Karen Sotiropoulos \\ Cleveland State University, k.sotiropoulos@csuohio.edu
}

Follow this and additional works at: https://engagedscholarship.csuohio.edu/clhist_facpub

Part of the African American Studies Commons, Political History Commons, and the United States

History Commons

How does access to this work benefit you? Let us know!

Publisher's Statement

This article first appeared in The Social Studies, 108:4, 121-128, DOI: 10.1080/

00377996.2017.1342160. Copyright Taylor \& Francis.

\section{Original Citation}

Karen Sotiropoulos. (2017). Teaching Black History after Obama, The Social Studies, 108:4, 121-128, DOI: $10.1080 / 00377996.2017 .1342160$

\section{Repository Citation}

Sotiropoulos, Karen, "Teaching Black History After Obama" (2017). History Faculty Publications. 107.

https://engagedscholarship.csuohio.edu/clhist_facpub/107

This Article is brought to you for free and open access by the History Department at EngagedScholarship@CSU. It has been accepted for inclusion in History Faculty Publications by an authorized administrator of EngagedScholarship@CSU. For more information, please contact library.es@csuohio.edu. 


\title{
Teaching Black History after Obama
}

\author{
Karen Sotiropoulos
}

\begin{abstract}
This article is a reflection on the teaching of black history after the Obama presidency and at the dawn of the Trump era. It is both an analysis of the state of the academic field and a primer on how to integrate the past few decades of scholarship in black history broadly across standard K-12 curriculum. It demonstrates the importance of theorizing black history as American history rather than just including African American content in US History courses and offers specific methods that can shift the narrative in this direction even within the confines of a more traditional telling of the American past. Finally, it situates the voluminous work of historians of the black past as critical interventions in pedagogy necessary to challenge today's unrelenting attacks on public education.
\end{abstract}

We who write Black History cannot track our "bleeding countrymen through the widely scattered documents of American History" and still believe in America. We can not see luster when we must glimpse it through oceans of tears. We cannot do not wish to write with detach ment from the agonies of our people. We are not satis tied to have our story accepted into the American saga. We deal in redefinitions, in control, in moving to set our own vision upon the blindness of American historiogra phy (Harding, 1970).

The Obama presidency made America "inhabit its history differently"-to borrow the words of Angela Davis, who explained "histories never leave us for another inaccessible place. They are a part of us; they inhabit us and we inhabit them even when we are not aware of this relationship to history" (Davis, 2012, p. 185). Debates about African ancestry and American citizenship-questions undeniably linked to America's slave past-infiltrated the presidency with the Obama administration, and his election exposed how entwined slavery and freedom have always been in American history, even though his paternal descent from an African student gave him a markedly different blood connection to the continent than the first lady (and most black Americans). That Donald Trump-the man who belligerently challenged Obama's citizenship and then failed to disavow the support of white nationalists during his campaignwas elected to succeed Obama encapsulates the symbolic power of his presidency and just how dangerous it has been to America's psyche to confront its origins as a slave republic. If Obama had the audacity to live through his presidency, the Trump administration has begun to assassinate his legacy, turning the struggle for black freedom back too many years to contemplate. What is ever more dear is that we must undertake with renewed vigor our job as educators and historians of the black past.

"History is not the past. It is the stories we tell about the past," scholar and activist Grace Lee Boggs imparted "How we tell those stories-triumphantly or self-critically, metaphysically or dialectically-has a lot to do whether we cut short or advance our evolution as human beings" (Boggs, 2011, p. 79). Trump's election should let us know just how transformative it was to have a president of African descent, and now more than ever, we must strive to give sight to the blindness of American historiography to explain to our children how we arrived at our present and how we might transform our future. I hope in this essay to argue the importance of theorizing black history as American history and to offer specific methods that can shift the narrative in this direction even in the confines of the traditional telling of the American 
past. This essay is both a reflection on the state of the field and a primer on how to integrate its insights broadly across standard curriculum.

The past 50 years of scholarship in African American history has pushed American historians to grapple more fully with the paradox of American slavery and American freedom, but the rich historiography of slavery and civil rights has still barely trickled down from the academy, despite the Obama presidency. I am continually surprised to discover how few college students have seen any episodes from Africans in America (1998) or Eyes on the Prize (1987), two widely available series produced by PBS that easily fit in any high school U.S. history course despite their historiographical limitations. Although education administrators pressure teachers of all levels to incorporate new technologies into the classroom, largely absent is any substantial support for integrating new knowledge into the curriculum-a predicament exacerbated by the stranglehold placed on 21st-century public educators with highstakes standardized testing determining much of what can be taught. The absence of Black Studies in the classroom can be explained in part by the decades-long backlash led by Christian fundamentalists and boosted under President George W. Bush's No Child Left Behind policy, a dynamic well demonstrated by the debates over U.S. history standards in Texas that became national news in 2010. At that time the Texas State Board of Education marshaled inordinate power to decide what or who could be included in the U.S. narrative, and discussions over whether to include figures, such as Thurgood Marshall or Cesar Chavez, occluded educators' efforts to introduce standards that measured critical thinking and analysis rather than those that supported the memorization of a "laundry list" of names (Erekson, 2012, p. 13). The narrowing of the debate toward one of inclusion or exclusion of a particular person tends to prohibit the interpretive practice that is at the core of historical thinking and makes it ever more difficult for teachers to draw on the past decades of substantial scholarship that has so dramatically revised our understanding of the American past. In Vincent Harding's view, this sort of approach lends itself to an older methodology of "Negro history" that attempted to "reveal the 'contributions' of blacks to the American saga" rather than the Black history interpretation he prescribed as the "plunge which refuses to fall prey to the American dream" (Harding, 1970, pp. 7, 15). Harding's 1970 essay reads like a manifesto for
Black Studies, the field itself spearheaded by the late 1960s student movement that historian Martha Biondi names the "black revolution on campus" (Biondi, 2012). In many ways, the decades-long backlash that erupted full force in Texas can be seen as an attempt to quell this intellectual revolution.

I found that with the son of a Kenyan and Kansan having now inhabited the White House, students are more eager to approach black history interpretations, including the scholarship of the past quarter century that situates the African American experience as part of a global African diaspora and places the story of the United States firmly in an Atlantic world context. Obama's international upbringing that included childhood years spent in Indonesia further casts his citizenship as global, and his identification as a black American, along with his modern internationalism, has helped students grasp the historical constructions of race by disaggregating Africa over time and space to glimpse a land and people with complex overlapping and divergent histories. But despite his blood connections to 20th-century Africa, Obama's sense of himself as a black man is grounded more in America's race narrative than that of postcolonial Kenya. Perhaps one of the best examples of the historic shift his presidency made lay in the simple fact that for eight years a first family descended from African captives inhabited the White House-a home built by slave labor. "I am married to a black American who carries within her the blood of slaves and slave owners," specified Obama in his pivotal campaign speech, "an inheritance we pass on to our two precious daughters" (Obama, B., 2008). Perhaps with even more force, Michelle addressed the Democratic National Convention saying theirs is "the story of generations of people who felt the lash of bondage, the shame of servitude, the sting of segregation, but who kept on striving and hoping and doing what needed to be done so that today, I wake up every morning in a house that was built by slaves-(applause)-and I watch my daughters-two beautiful, intelligent, black young women-playing with their dogs on the White House lawn" (Obama, M., 2016). With the Obama presidency, the history of enslaved Americans no longer spoke from the margins; rather, its descendants inhabited the Oval Office. That Malia and Sasha descend from the first lady as well as the president also tells a significant tale. After all, evidence points toward at least one of America's earliest presidents as 
having fathered children with an enslaved woman, which means black blood relations of an American president inhabited the White House at least at some point. The story here is that Malia and Sasha are the president's wife's daughters - the progeny of the president and the first lady. This turn of events seems to beg for a paraphrase of an observation James Baldwin once directed to a white segregationist: "You're not worried about me marrying your daughter," he retorted, "you're worried about me marrying your wife's daughter. I've been marrying your daughter since the days of slavery" (Killens, 1965).

This lineage presented Americans with a clear presidential link to the nation's enslaved ancestors and placed the stories of American and New World freedom that their life histories told at the center of the American narrative. With Michelle's mother inhabiting the White House as well, family dinner conversations must have had a decidedly different slant. Michelle's parents, Jim Robinson and Marian Shields, descend from among the estimated 20 million people torn from the African continent for more than the 300 years of the Atlantic slave trade. Her third great-grandmother on her mother's side, Melvinia Shields, born circa 1844, enslaved in South Carolina, and once valued at $\$ 475$, now has a monument commemorating her life. Jarrod Shields, who descends from the family that owned Melvinia, offered apologies at the monument's dedication ceremony saying, "My family is the ones who did it. At some point, we've got to break the curse, y'all" (Riquelmy, 2014). I bring this up not to praise, nor critique Shield's blunt honesty, but to recognize the significance of the shift that brought him to the dedication-a change that has turned America's eye to the legacy of slavery and somewhat brutally exposed the ongoing deep-seated racism still prevalent in the nation. Melvinia Shield's own grandparents were likely among the 12 million captives who survived the Middle Passage to the New World, an estimated 450,000 of whom arrived in British North America and the early United States. This forced movement of peoples meant that a fifth of America's population at the time of the Revolution had blood ties to a black world that spanned continents but is still generally relegated to the margins in most U.S. (and even many African American) history textbooks, with little more than a passing reference to African origins.
Although there has been a tremendous shift in public representations of America's slave past-some of it during the time of Obama's presidency-these depictions fail to centralize narratives of black America as U.S. history. Many of my students now come to class either having already seen Twelve Years a Slave or watched it under my recommendation during the semester. Steve McQueen's startling portrayal does not shy away from the multiple forms of violence endured daily by enslaved Americans and heightens students' sensitivities to the horror in the institution, but it does not destabilize their ideas about race in America. Although the release of Nate Parker's Birth of a Nation and the opening of the African American History Museum provide more accessible source material, it remains unclear how much even they will shift the story from margin to center in American classrooms without the active mainstreaming of a black history perspective. For too many students who were genuinely moved by Twelve Years a Slave, the human drama lay in Solomon Northrop's wrongful enslavement, rather than the ways that his color defined him as un-free. White and black alike, they expressed joy at Northrup's return to his family, individually identifying with his struggle without considering the masses of enslaved blacks left behind or the story of the institution's formative role in the nation's making. As one student wrote, "Never in my life have I seen being black as a bad thing, but how I wished he were born white, just to avoid the pain he suffered through." The film ends with a bittersweet image of Northrup's emancipation as his daughter hands him his infant grandchild. Slavery remains abstract, an institution of the past and the South that involved "them" not "us," rather than a story of human greed and dogged resistance to captivity that constructed race in the New World.

To centralize New World captivity as critical to America's founding and the history of race-making, I begin most of my courses with two images: Elmina Castle in Cape Coast, Ghana, and Plymouth Rock in Plymouth, Massachusetts. It just so happens that both pictures are my own travel photos, which I find helps in developing rapport with students. However my point is not that I've been to these locales, but that they are both sites where we can mark different defining moments of American origins. The migration commemorated by the Massachusetts rock encompassed roughly 20,000 of our American ancestors who 
set sail from Europe during the two decades after 1620 , hoping to settle somewhere to practice their faith. But during the centuries that followed, more than 20 times as many of our American ancestors dwelled in slave forts like Elmina on the West Coast of Africa before being shipped in chains to the slave ports of British North America and the early United States. No marginal institution, race-based chattel slavery expanded so much that by 1850, 3.2 million Americans were enslaved in the United States and had a market value of $\$ 1.3$ billion, or "one fifth of the nation's wealth and almost equal to the entire gross national product" (Baptist, 2014, p. 352). To be sure, highlighting America's original sin in U.S. history courses is hardly a new phenomenon, but I find students surprised-and many of them seriously challenged-when I center the institution and its legacy in the story of American democracy, placing slavery's fierce opponents, both enslaved and free, as America's innovators of freedom rather than the slaveholding founding fathers. Instead of addressing slavery, but then marching on to embrace a narrative of a progressively freer America, students are forced to look at all of the nation's history through the eyes of the enslaved and their descendants, a perspective welcomed by virtually all my black students as well as a large majority of my white students. By situating Elmina at the center of the U.S. story, I have found that all but the most resistant students begin to question the traditional narrative and periodization of freedom and democracy by the semester's end. It is this vision that ultimately drives my pedagogy and insists how America must inhabit this history-black history as its history.

In this telling the legacy of slavery and the long struggle for black freedom becomes the central narrative of America and highlights how much American history has always been international at its core-in no small way due to the massive demographic shift of the forced dispersal of African peoples to the New World. It profoundly disrupts the dominant periodization of American history, answering in some ways Vincent Harding's 1970s call for a black history that would redefine "the blindness of American historiography." Harding more recently reformulated this idea by drawing on the words of a West African poet who recited sometime in the 1960s, "I am a citizen of a country that does not yet exist." Inspired by the hope of African independence (as was Barack Obama Sr.), this poet evoked not the nation within a nation of
New World black nationalist thought but rather, as Harding translated for the 21 st century, alluded to a nation that "we still have to create ... a just country, a compassionate country, a forgiving country, a multiracial and multi-religious country, a joyful country that cares about its children and about its elders, that cares about itself and about the world, that cares about what the earth needs as well as what individual people need" (Edelman, 2014). This nation's founding moment lay sometime in the future-an achievement seen through the perspective of the enslaved, the Jim Crowed, and all those struggling to dismantle U.S. systems of white supremacy. In essence, then, what I have been striving to do in my courses is to will Harding's country into existence by writing its history-a history that arguably began somewhere in the slave dungeons of West Africa, was transformed by the tortuous intimacies of the slave ship, and continues to shape the time and space of American freedom-a freedom that did not come with the U.S. founding but has yet to be achieved. This country, as Harding surmised, was once imagined by poet Langston Hughes who wrote: "O, let America be America again/the land that never has been yet/and yet must be-the land where every man is free...America never was America to me, And yet I swear this oath-America will be!" (Hughes, 2004).

Teaching this sort of history forces a global positioning of black Americans in regard to the Americas and to Africa and re-imagines the United States and the world through the future of a black past by rewriting the entirety of U.S. History. While this approach to time and space changes depending on the specific course topic, the attention to transnational black ties has made it impossible for me to teach the Plessy $v$. Ferguson "separate but equal" decision without placing it alongside black America's attention to Ethiopia's triumph over Italian colonizers that occurred the same year. I can't address World War II without beginning with the thousands of black Americans who wanted to fight Mussolini side by side with Ethiopians in 1935, several years before the United States conscripted black soldiers in segregated troops to fight the same European fascist. I can't discuss the Brown decision or lynching of Emmett Till without looking through the eyes of black Americans who attended the Afro-Asian Conference in Bandung, Indonesia, a worldwide gathering that occurred between these two events marking the anticolonial march of the black and brown world. 
Each of these eras deserves equal amounts of discussion, but because there is not space in this essay to cover them all, I focus on just two foundational moments: the transatlantic slave trade and the American Revolution. What follows then is further discussion of materials and methods that should help in reframing American history in ways that might begin to answer Vincent Harding's call to centralize black history as the defining story of American freedom.

\section{The transatlantic trade in African human beings}

Shifting the language used to discuss slavery is critical in changing the narrative, and I have all but eliminated calling anyone a "slave," but rather make clear that the action done to the human being by using terms like captive, enslaved African, or enslaved American depending on the time and space of the individual's position in the trade. I find that once begun, this practice infuses my lectures and my students' writing in ways that make clear how the transatlantic trade commodified human beings. In effect, the institution turned human beings into slaves in the eyes of the market but did not change the captives' own self-conception (Smallwood, 2007). To begin this discussion, I often integrate Marcus Rediker's opening from his Slave Ship: A Human History-a description of the human drama of Atlantic world slavery told from the perspective of a captive Igbo woman (Rediker, 2007). When time and course content allow, I read aloud directly from Rediker's book as student feedback has confirmed for me that the intimacy of hearing the stories of human travails without the comfort of dim lights and photographic or video reproduction humanizes some historical experiences far more successfully. The subject of study is no longer "them"; they are us. For this reading I do keep an image up on the screen-a graphic of numbers and routes of dispersed Africans to the New World drawn from the magnificent companion website to David Eltis and David Richardson's Atlas of the Transatlantic Slave Trade (2009), www.slavevoyages.org. This juxtaposition emphasizes that hers is but one account of the millions of captives who approached the slave ship. By narrating the story through the eyes of this one woman, Rediker rescues millions from what he called the "violence of abstraction" by vividly evoking her experience through the senses-a human history of sight, sound and smell.

\begin{abstract}
"She had traveled three moons from the interior, much of it by canoe down the rivers and through the swamps. Several times along the way, she had been sold...now she wiggled upward against the wet torso of another prostrate captive...the wind picked up, and she caught a peculiar but not unfamiliar odor of sweat...the ship grew larger and more terrifying with every vigorous stroke of the paddles...the smells grew stronger and the sounds louder crying and wailing from one quarter and low plaintive singing from another; the anarchic noise of children given an underbeat by hands drum ming on wood; the odd comprehensible word or two wafting through; someone asking for menney, water, another laying a curse, appealing to myabecca, spirits" (Rediker, 2007, p. 1 2).
\end{abstract}

Interspersing his account with Igbo words, Rediker shows the intimacy of how this woman struggled to make sense of the slave ship-of the white and black traders who ruled this world and of her new community of fellow captives. He recounts how sharks foiled her attempted escape and how she later witnessed the swirl of blood left by some sick and dying women who had been thrown overboard as they became food for those sharks she had seen circling below.

By hearing this human history read aloud students can better imagine how the captives did not think of themselves as "African" as they approached the ship and, thus, to consider how people from the continent encountered and created modern ideas about race. Furthermore, with reference to slavery not as an abstract system but as a human perpetrated and endured horror, students can take the opportunity to rethink America's origins and constructions of race. This Igbo woman had entered the intimacies of a new world among human cargo and was about to shape a new community formed by the shared suffering of the Middle Passage. The first person account helps undergraduates envision histories of slavery, freedom, and race from the human captive's standpoint. They then can more easily navigate texts, such as Stephanie Smallwood's Saltwater Slavery and Michael Gomez's Exchanging Our Country Marks to think through the point of view of Igbo, Wolof, Bambara, and so many others to trace how a diversity of peoples from the continent came together as a racially defined community. Even when I cannot include these books on the syllabus, the captive Igbo women's story helps introduce the complex stories of racial identities formed in 
struggle. As Gomez writes, the Middle Passage was both a death canal and a birth canal-giving birth to a new sense of self as communally "black," and as Smallwood describes, captives generated new community amidst the horror of human bondage to create kin amidst the "purgatory of perpetual kinlessness" (Gomez, 1998, p. 13; Smallwood, 2007, p. 61).

With death ever present in the Middle Passage, mourning rituals inevitably played an elevated role in how the many different peoples captured in Africa came together in New World black communities. Stories about the past united surviving captives who drew on a vast variety of beliefs to send the departed to their gods, and in turn, created New World black identities. The documentary film The Language You Cry In well demonstrates this theme by showing how black women across generations connected through an ancient Mende funerary song that survived the Middle Passage. As late as the 1990s a South Carolinian woman named Mary Moran still sang the Mende lyrics her mother had taught to her, and her grandmother had taught her mother: "Everybody come, everybody come together-the grave is not ready-is not yet at peace." Although Moran did not know the lyrics she sang were Mende until researchers shared the translations with her. The song's place of significance in her life suggests just how conscious the struggle to survive as a people was among the enslaved and how much black people linked past and present, making themselves through conscious human creativity. As Mende elder, Nabi Ja sums up "You can speak another language, you can live in another culture but to cry over your dead you always go back to your mother tongue-the language you cry in" (Serrano and Toepke, 1998). It is not necessary to show this film or teach Rediker's book to integrate the stories they tell into the curriculum. Centralizing these perspectives in a variety of ways can anchor black history as American history and can narrate an "America that will be" - a nation with a timeline of freedom that begins with Elmina and the Middle Passage as points of origin, carries through the revolutionary era, and redefines the U.S.'s position as an Atlantic world nation.

\section{The American revolution in the Atlantic world: George and Henry Washington}

The American Revolution is perhaps one of the most startling markers for students because it forces them to consider why and how a revolution purportedly for freedom and democracy left 20 percent of its population enslaved. Rather than situating the American Revolution in a narrative that looks back from the Civil War as the inevitable second revolution ending formal slavery, I ask students to look through the eyes of those held captive in the British colony to consider the establishment of the United States in an Atlantic world context that included the founding of Sierra Leone (1787), Haiti (1804), and Liberia (1820). This positioning emphasizes further how enslaved British North Americans might consider Britain to be the enemy of one's enemy. American captives would undoubtedly hold a different view of their masters' fight for independence, of the two West African nations established by Western powers, and perhaps even more powerfully, of the Caribbean nation whose revolution ended slavery along with French rule.

In nearly every course I teach, I illustrate this part of the narrative by drawing on a story of an enslaved American freed by British courts four years before the signing of the Declaration of Independence. What became known as the Somerset decision was "widely interpreted as having abolished slavery in Britain," and as such, the case points toward new questions about America's founding fathers' motivations. Born in Africa and transported to Virginia, James Somerset was purchased by Charles Steuart who brought him to England in 1769 where two years later he managed to escape. Steuart recaptured him and then set him on board a ship headed to Jamaica for sale there, but British abolitionists took on the case, winning Somerset's freedom as the courts decided Steuart had no right to sell him (Sinha, 2016, pp. 22-23). A relatively straightforward case to teach, Somerset's story awakens students to the possibility that the American Revolution was, in part, a slaveholders' rebellion with slaveholding colonists seeking to maintain legal ownership of human beings while the mother country had signaled the institution's formal demise. Four years after the Somerset case, Thomas Jefferson-who over the course of his life would count over 600 people among his possessions-drafted the Declaration of Independence.

Perhaps no figure better illustrates the need for rewriting U.S. history from a black perspective than that of the nation's first president who is generally remembered for having freed his human property posthumously. On the eve of the American Revolution, Washington held 150 people in captivity, and although he wrote he would like to "get quit of 
Negroes," he went to great lengths to maintain possession of the people he owned even as he relocated to northern cities already in the process of abolition. When he resided in Pennsylvania, he subverted the Gradual Abolition Act of 1780 that declared free anyone who lived there in excess of six months by sending his captives out of state at the deadline to reset the clock. Furthermore, he not only signed the first Fugitive Slave Law but he actively pursued Ona Judge, a young woman who had run away from him, until weeks before he died (Dunbar, 2017). The historical memory of Washington as one who desired an end to slavery was in no small way shaped by black ministers who, at the time of his death, drew on the words of his will rather than his deeds to fashion a rhetoric supportive of their abolitionist cause (Sinha, 2016, p. 149).

The history of another of Washington's captives sheds even more light on black Americans' political location to the U.S. founding as well as to Britain and the new nations of the Atlantic world-a kind of geography of freedom. Born in Africa, transported to America, and owned by the first U.S. president, Henry Washington had fought against America's slaveholding revolutionaries with Lord Dunmore's Ethiopian Regiment in 1776, and after the war, was stationed with other Loyalists in Charleston and New York before being evacuated to British Nova Scotia. Unhappy with his treatment in Nova Scotia, he, his wife and three children left with a British-financed expedition to join a free black community in Sierra Leone in 1791. With the end of the slave trade in sight, Britain had founded Sierra Leone to help suppress a growing free black population at home through colonization and to aid in dispensing with the human cargo from slavers still active in the Atlantic. The American Colonization Society founded Liberia for similar reasons a few decades later, and the stories of black emigrants to these two West African nations have been intertwined ever since. Many black North Americans who immigrated to Sierra Leone and Liberia would soon discover themselves trapped in a new colonial world rife with painful contradictions. Some worked for the slave forts still active in the region; others discovered that more than a few African kings made rich by trading in human beings resented the teetotaling New World abolitionists who sought an end to the slave trade. And some, like Henry Washington, battled other blacks from the diaspora in colonial wars. Not too long after arriving in Sierra Leone, Washington joined a group resisting increasingly rigid British rule and found himself fighting Jamaicans from a maroon community who the British had shipped in chains from their island colony to their new West African possession to help them suppress the uprisings (Campbell, 2006, p. 27).

Henry Washington's dizzying experiences from African captive to African rebel make clear that the U.S. saga is no simple story of American or African, black or white, but rather encompasses how human beings envisioned their belonging to a land and its people - a history that had everything to do with one's location in the slave trade. Washington's tale does not fit neatly into American, African, or British colonial history but rather deserves to be a driving narrative that refocuses the Atlantic world. His is just one of many stories that clarifies how much the trade was not about "brother selling brother" but rather rested in a complicated narrative of precolonial Africa, European guns, money, power, and nation building. The expansion of wealth with the commodification of human beings reveals a rapidly accelerating capitalist global economy where Europeans dominated markets and where the human survivors of the trade would over time give birth to themselves as a community of black folk as they shared in the suffering of the unimaginable torture of the Middle Passage, mourned their dead, and dreamt of freedom.

Journalist Ta-Nehisi Coates intimately evokes this connection between black power, black history, and his own sense of self as a black man in his widely acclaimed book Between the World and Me. "Black power," explained Coates, "is the dungeon-side view of Monticello-which is to say, the view taken in struggle"; if the dominant narrative of American history "made us into a race," it was that view from the slave dungeons, from captive Africans, that "made us into a people." Blackness itself, for Coates, was created in the shared struggle of a diversity of people of African descent. "We made that feeling, though it was forged in the shadow of the murdered, the raped, the disembodied, we made it all the same" (Coates, 2015, pp. 120, 149). The legendary musical artist Smokey Robinson similarly suggested this definition of race in his spoken word poem "A Black American," a powerful six-minute performance that has also made its way into most of my courses. "Black is not our color. It's our core/It's what we been livin' and fightin' and dyin' 
for," recites Robinson (Robinson, 2003). It is this narrative of race that shaped President Obama, a hybrid identity formed in struggle and originating among the blood of the peoples who made up the cargos of the slave ships traveling to the New World.

Out of human agonies, shared struggle, and dreams of freedom came the making of a people. If there is a free new nation-a free America that "will be"-then it will need to start from the guarantee of the freedom to be black. As singer-songwriter Solange Knowles tweeted shortly after the Charleston massacre, "Was already weary. Was already heavy hearted. Was already tired. Where can we be safe? Where can we be free? Where can we be black?" (Capehart, 2015). So, the struggle continues, even-or especially-with the changes evidenced by the Obama presidency and its backlash vividly embodied by Donald Trump's hateful, fear-driven, bombastic campaign and presidency. Ta-Nehisi Coates poignantly sums up this state of affairs affirming that too many Americans "have forgotten the scale of theft that enriched them in slavery; the terror that allowed them, for a century, to pilfer the vote; the segregationist policy that gave them the suburbs," because too many Americans would "rather live white than live free" (Coates, 2015, p. 143). Historians of the black past continue to have a most important role in steering America to a new way to inhabit the dungeon side of its past; they can help "blacks and everyone in this country develop a common understanding of the important role that the black struggle for human rights has played through the years not only to advance blacks but also to humanize this country" (Boggs, 2011, p. 79). The Obama presidency has forced Americans to confront this different story about our shared past-a story of a black struggle for humanity that made us all more free. The Trump presidency makes our task as educators all that more urgent.

\section{References}

Baptist, E. E. (2014). The half has never been told: Slavery and the making of American capitalism. New York, NY: Basic Books.

Biondi, M. (2012). The black revolution on campus. Berkeley, CA: University of California Press.

Boggs, G. L. (2011). The next American Revolution: Sustainable activism for the $21^{\text {st }}$ century. Berkeley, CA: University of California Press.

Campbell, J. (2006). Middle passages: African American jour neys to Africa, 1787 2005. New York, NY: Penguin.
Capehart, J. (2015, June 18). A black day in Charleston. The Washington Post. Retrieved from https://www.washington post.com/blogs/post partisan/wp/2015/06/18/a black day in charleston/

Coates, T. (2015). Between the world and me. New York, NY: Random House.

Davis, A. Y. (2012). The meaning of freedom and other difficult dialogues. San Francisco, CA: City Light Books.

Dunbar, E. A. (2017). Never caught: The Washingtons' relent less pursuit of their runaway slave, Ona Judge. New York, NY: Atria Books.

Edelman, M. E. (2014, May 30). Dr. Vincent Harding's Call to Make America America. The Huffington Post. Retrieved from http://www.huffingtonpost.com/marian wright edel man/dr vincent hardings call b $5420254 \mathrm{html}$

Eltis, D., and Richardson D. (2010). Atlas of the transatlantic slave trade. New Haven, CT: Yale University Press. Retrieved from www.slavevoyages.org.

Erekson, K. (Ed.). (2012). Politics and the history curriculum: The struggle over standards in Texas and the nation. New York, NY: Palgrave Macmillan.

Gomez, M. A. (1998). Exchanging our country marks: The trans formation of African identities in the colonial and antebellum south. Chapel Hill, NC: University of North Carolina Press.

Harding, V. (1970). Beyond chaos: Black history and the search for the new land. Black Paper No. 2. Institute of the Black World.

Hughes, L. (2004). Let America be America again and other poems (1st Vintage Books ed.), New York, NY: Vintage Books.

Killens, J. O. (1965, August). Would you want one to marry your daughter? Negro Digest.

Obama, B. (2008). A more perfect union. Retrieved from http://constitutioncenter.org/amoreperfectunion/

Obama, M. (2016). Remarks by the first lady at the Democratic National Convention. Retrieved from https://www.white house.gov/the press office/2016/07/25/remarks first lady democratic national convention

Riquelmy, A. (2014, September 21). Monument to First Lady Michelle Obama's ancestor Melvinia Shields dedicated at Kingston church. Rome News Tribune. Retrieved from http://www.northwestgeorgianews.com/rome/news/local/ monument to first lady michelle obama s ancestor melvi nia shields/article 24b5927c 4159 11e4 91c5 0017a43b 2370.html

Rediker, Marcus. (2007). The slave ship: A human history. New York, NY: Viking Press.

Robinson, Smokey (2003). A black American. Def Poetry Jam, Season 3, Episode 7 (DVD released 2013).

Serrano A. (Producer), and Serrano A. \& Toepke A. (Direc tors). (1998). The language you cry in. California News Reel. New York, NY: Films Media Group.

Sinha, M. (2016). The slave's cause: A history of abolition. New Haven, CT: Yale University Press.

Smallwood, S. (2007). Saltwater slavery: A middle passage from Africa to American diaspora. Cambridge, MA: Harvard University Press. 